\title{
Jubileum Jóhanna Pálla Árnasona
}

Profesor Jóhann Páll Árnason letos oslavil své sedmdesáté narozeniny, což poskytuje příležitost popřát mu na stránkách časopisu Historická sociologie vše nejlepší a hodně zdraví, mnoho pedagogických zážitků s českými studenty a také inspirativní a plodnou spolupráci s českými kolegy. Zároveň snad jde také o vhodnou př́ležitost k tomu, abychom alespoň stručně připomněli vztah profesora Árnasona k českým sociálním vědám obecně a k sociologii zvláště.

Tento př́iběh začíná, když se devatenáctiletý mladík z Islandu Jóhann Árnason roku 1959 ocitá v Mariánských lázních na kurzu českého jazyka pro cizince. Ačkoliv již naplno pokračuje studená válka, ve které se Island jako strategický člen NATO nachází na druhé straně barikády, mezi Islandem a Československem funguje až do 60. let 20. století relativně intenzivní studentská a kulturní výměna. Zájem mladého muže o Východní blok je však v této době motivován jednoznačně ideologickými důvody, nikoliv touhou po nevšedních akademických dobrodružstvích a inspiracích, které přijdou na řadu až o něco později. Jako člena islandské komunistické strany (tato strana se však lišila od tehdejších komunistických stran na evropském kontinentu, byla např́klad konstruktivní součástí řady vládních koalic) ale v Československu čekala mladého Árnasona postupná deziluze.

Již jako student filozofie a historie na Filozofické fakultě Karlovy univerzity (1960-66) se Jóhann Árnason stal svědkem počátků destalinizace (po XXII. sjezdu KSČ v roce 1961) a oficiálního přiznání ekonomické krize (KSČ v roce 1962 poprvé uznává negativní růst hospodářského produktu). Poté přichází snaha o reformy vrcholící dramatickými událostmi ze srpna 1968. K tomu jubilant v nedávném osobním rozhovoru poznamenal: „Byla to politicky velmi komplikovaná a složitá doba, ale naprosto fantastická a inspirativní pro studium, zejména pro studium humanitních disciplín.“

Za výrazné osobnosti svých studentských let profesor Árnason pokládá filozofa a fenomenologického marxistu Jiřího Peška, ale zejména Karla Kosíka: „Tady začíná moje konverze k fenomenologickému marxismu“. Kromě toho v Praze dochází také k ovlivnění Janem Patočkou, který směl opět od roku 1963 omezeně přednášet na Filozofické fakultě Univerzity Karlovy (pouze pro učitele fakulty, nikoliv př́mo pro studenty). Mezi nejzásadnější Patočkův text Árnason řadí stał „Nadcivilizace a její vnitřní konflikt“, originálně pojednávající o modernitě, se kterou se však seznámil mnohem později.

K původně plánovanému dlouhodobějšímu návratu do Čech (Árnason strávil krátkou dobu v Římě a pak působil na Islandu) však již nedochází, let do Prahy rezervovaný na 23. srpna 1968 je po invazi sovětských vojsk zrušen. Následují proto v letech 1968-1970 studia sociologie a filozofie u Jürgena Habermase ve Frankfurtu nad Mohanem, zakončená doktorským titulem. Pedagogická či badatelská kariéra zahrnuje působení na řadě univerzit a výzkumných institucí: nejprve v Německu, poté v Austrálii, ve Francii a také v Japonsku (sabatikal 1991-1992). Studium dlouhodobé sociální změny japonské společnosti stálo v pozadí iniciace intenzivnějších kontaktů Jóhanna P. Árnasona a Shmuela N. Eisenstadta. 
V této souvislosti se nabízí otázka, do jaké míry je nutný „ponor“ a zažitá zkušenost s různými kulturami a společnostmi pro úspěšné bádání v oboru historické komparativní sociologie. Profesor Árnason k tomu ve zpětném pohledu říká: „Styk s různými sociálními světy je zde důležitý, dlouhodobý pobyt v zemi socialistického tábora mě patrně opravdu velmi ovlivnil.“

V současné době profesor Árnason své bádání označuje Krejčího pojmem civilizacionistika: „Můj post-marxistický obrat k civilizacionistice byl dán zejména intenzivní četbou Maxe Webera a Émila Durkheima, kromě toho jsem výrazně inspirován také fenomenologií a hermeneutikou a možná bych se mohl charakterizovat i jako post-weberián“. Nejnověji se v této oblasti profesor Árnason angažoval v diskuzích o různorodých modernitách („multiple modernities“), které byly popularizovány publikováním monotematicky zaměřeného čísla časopisu Daedalus v roce 2000. Tato myšlenková škola se pokouší překonat nejen klasické modernizační paradigma vzniklé v období studené války, ale také koncepty sociální změny, dominující po zhroucení Sovětského svazu (konec historie a střet civilizací).

Kolaps sovětského komunismu, který Árnason chápe jako projekt alternativní modernity s imperiálními ambicemi, oslavenec analyzoval v knize The Future that Failed z roku 1993. Opírá se přitom o teorie demokracie a totalitarismu z pera méně známých francouzských sociálních myslitelů Cornelia Castoriadise a Clauda Leforta. Další alternativní verzi modernity, kterou se Árnason podrobně zabývá, představuje Japonsko. V knize Social Theory and Japanese Experience ( $\mathrm{z}$ roku 1997) autor analyzuje rozdílnosti a podobnosti středověkého Japonska a feudální Evropy, roli éry dynastie Tokugawy na japonskou sociální transformaci a japonské vzorce modernity. Později vyšla obecněji zaměřená rozsáhlá kniha esejů s názvem The Peripheral Centre: Essays on Japanese History and Civilization (z roku 2002). Systematické rozpracování civilizační analýzy se pak objevuje např́klad v knize Civilizations in Dispute, publikované v roce 2003. Ta se objevuje v době zvýšeného zájmu o problematiku civilizací (ał již mezi publicisty fascinovanými koncepcí „střetu civilizací“, nebo mezi seriózně uvažujícími akademiky) a pokouší se o poctivější teoretickou reflexi této problematiky (čtenář v této knize nalezne systematické a kritické shrnutí klasických i současných přístupů k civilizační analýze). Dále se český čtenář o civilizační analýze může dočíst v knize Civilizační analýza: Evropa a Asie opět na rozcestí (Filosofia, 2009), konečně pak relevantní texty jsou v českém jazyce uspořádané také v nejnovější publikaci Historicko-sociologické eseje (SLON 2010).

Cílem tohoto textu však není vyčerpávající přehled všech děl a životních fází jedné impozantní badatelské kariéry, nýbrž připomínka významného životního jubilea. Zde snad ještě uved’me monumentální knihu Axial Civilizations and the World History z roku 2005, redigovanou spolu se Shmuelem N. Eisenstadtem a Björnem Wittrockem.

Životní a akademický rytmus dnes profesorovi Árnasonovi určuje primárně střrídání ročních období: kratší léto tráví na Islandu a zimu pak v České republice, kde se angažuje zejména na Fakultě humanitních studií Univerzity Karlovy v Praze. Hodí se dodat, že jubilant je stále emeritním profesorem na La Trobe University v Melbourne (Austrálie).

Na závěr proto nejen profesoru Jóhannu P. Árnasonovi, ale i sobě, popřejme, aby se mu v České republice stále líbilo a svá „zimní období“ často a rád chápal jako časový úsek začínající nejméně babím létem a končící nejdříve velmi pozdním jarem.

Karel Černý 